\title{
INCREASING YIELDS OF WINTER WHEAT BY MEANS OF SOWING ORIENTATION OF GRAIN
}

\author{
Tetiana Kuzina ${ }^{1}$, Victor Sirenko ${ }^{1}$, Vladyslav Zubko ${ }^{1}$, Viacheslav Chuba $^{2}$ \\ ${ }^{1}$ Sumy National Agrarian University, Ukraine; ${ }^{2}$ National University of Life and Environmental \\ Sciences of Ukraine, Ukraine \\ 300860@ukr.net, snaumen105@ukr.net, zubkovladislav@ukr.net, vvchuba@ukr.net
}

\begin{abstract}
By means of the studies of the influence of the method of sowing of winter wheat grains containing germs oriented upwards, the increase of the wheat yields in comparison with the traditional horizontal position of the sown grain was established. The mechanism of the physiological process of the promotion of growth of the primary roots and wheat stems in the course of germination is revealed. Shou-Chen Ma studied the effect of the sowing time and sowing rate on the yield components and winter wheat use efficiency. Bakhram Andzaryan was engaged in determining the optimum date of sowing of wheat using the model CSM-CERES-Wheat. We are investigating the increase in the wheat yield by oriented seeding of the grain. The experimental studies confirmed the accelerated growth of the indicators of the weight and size of wheat, sown vertically with the germs oriented up wards, in comparison both with the germs oriented downwards and by means of the horizontal sowing method. The crucial influence of the methods of grain orientation in the soil on the background of the optimum depth of the position of the germ, when the level of moisture of the soil is determined, both on the process of vegetation and the yield, has been proved. Besides, it is established that due to the application of the vertical sowing method, when germs are oriented upwards, and the advanced vegetation of all parts of the plant, such as: the root system, stem, head and grain, the yield of winter wheat can be increased by $32 \%$, in comparison with the control samples. We can state that the mechanism of wheat growth promotion and the possibility for introducing it into an expanded classification of methods, used to enhance the germination activity of plants, while applying a wide range of pre-cultivating methods of the sowing material, can be confirmed. Thus, the obtained results show an advantage of the sowing method, when the germ is oriented upwards, expressed in the increase in the yields, both quantitatively and qualitatively. The results also indicate the attractiveness of such technical means for crops oriented specially.
\end{abstract}

Key words: winter wheat, germ, orientation, method of sowing, vegetation.

\section{Introduction}

The main international and national food crop is winter wheat. The effectiveness of wheat cultivation depends on the biological, natural and agronomic factors, namely: cultivar, reproducibility, vegetation conditions (temperature, water), nutrition, cultivation technologies.

According to [1], the maximum biological yield of the short-stemmed wheat is at $90 \mathrm{c} \cdot \mathrm{ha}^{-1}$. The technologies of short-stemmed wheat growing, used in Ukraine, allow us to get the yield at a level of $53-55 \mathrm{c} \cdot \mathrm{ha}^{-1}$, which comprises $60 \%$ of the biological yield.

The productivity of winter wheat depends on a number of key factors that should include the weather conditions, biological potential of the sowing material and adherence to the agronomic requirements for cultivation $[2 ; 3]$. The meteorological factors are quite changeable and cannot be controlled; we can only predict them and adapt to. The application of irrigation allows us not only to reduce the probability of the drought effect on winter wheat yield, but also to increase the cost of cultivation significantly [4].

After germination of the winter wheat seedlings, a set of possible agricultural methods, aimed to increase its yield, is very narrow $[5 ; 6]$. One of the main ways to increase the yield and quality of the grain is the timely fertilization of plants with the necessary fertilizers and trace elements, but this impact is quite limited and expensive [7;8].

The effect of the sowing time and sowing rate on the yield components and winter wheat use efficiency has been studied [24], determining the optimum date of sowing of wheat using the models [25].

In the cultivation of winter wheat, the importance of performing the pre-sowing seed processing operations and the implementation of the agricultural and technological crop operations as the sources of the accelerated physiological vegetation of plants was noted $[9 ; 10]$.

The pre-sowing seed preparation should be provided with the choice of the sowing material selected according to the geometric parameters and germination to ensure the activation of the 
germinating capacity. Many studies are aimed at finding the activation tools, promoting the acceleration of the germination and vegetation of the germ of the grain. The effect of the changes in swelling [11] and drying of the sowing material and the influence of the ultraviolet irradiation and solutions of the mineral salts on the physiological properties of wheat seeds and their germination were studied in the investigations. The simultaneous cultivation of winter wheat grains by means of the electromagnetic irradiation and growth promoter can significantly increase the seed germinating capacity [12]. At present, the impact of the laser irradiation [13], the infrared irradiation of various wavelength ranges [14], the electromagnetic and magnetic fields $[15 ; 16]$ and the gas discharge in the form of plasma [17] on the increase in the capacity of germination has been confirmed by the scientific studies. Taking into account the required preparation volumes, it is necessary to underline that the application of the methods, used for increasing the seed germination efficiency, mentioned above, requires a substantial investment in the technological equipment. It should be noted that, along with the positive effect of such a preparation, there is a significant risk of inhibition of the sowing material caused by a rather severe exposure to irradiation, radiation, chemicals and mechanical damage.

The analysis showed a variety of existing methods aimed to enhance the intensification of the vegetation of the grain crops. But it should also be noted that these methods are limited and rather expensive. In our opinion, one of the effective methods applied to enhance the growing efficiency of the grain crops is to ensure the proper placement of the grain in the soil during sowing. The proper placement should provide the grain with the most energy for the vegetation of the root system, promote the vegetation of the plant and increase the qualitative and quantitative indices of yields.

The purpose of the research is to study the influence of the technological parameters and geotropic factors both on the intensification of the vegetation stages of the plant and also on the qualitative and quantitative indices of the yields of winter wheat during sowing.

To achieve the aim, the following tasks were solved:

- to investigate the influence of the geometric position of the "germ" of winter wheat in the soil on the vegetation indices of the plant during sowing;

- to find out the peculiarities of the yields of winter wheat during the entire period of vegetation in the field conditions, when applying the traditional horizontal and the vertical position of the seeds, such as the downward and the upward orientation of the germ;

- to determine the influence of the direction of the grain seeds on the features of the elements of the morphology of heads and grains of wheat, which determine the qualitative and quantitative indices of the yields.

\section{Materials and methods}

To achieve this aim, laboratory and field studies of the effect of the non-standard vertical position of grains, both with the downward and the upward orientation of the germ, at different depths of seed placement, were performed on the magnitude of the expected positive effect of the germ.

In the laboratory of the Sumy National Agrarian University, the germination of such elite class cultivar of winter wheat seeds with the grain weight of 0.054-0.056 grams as "Bogdana" was checked and a two-factorial experiment aimed to study the influence of the orientation of the grain germ and the depth of its placement on germination and growing capacity was conducted. For measure of the herb a micrometer was used.

To verify the obtained laboratory data and to determine the influence of the geometric position of the germ during winter wheat harvesting on the full vegetation and qualitative and quantitative indices of yield, some field experiments were conducted. The grain of winter wheat "Bogdana" was used as the sowing material without preliminary pre-planting preparation with a seeding density of 5 million units per hectare. To carry out the directed sowing of the germ, an experimental sample of the seed section with a disc-rolling coulter was used [18]. The experimental fields of the Faculty of Agricultural Technologies and Nature Management of the SNAU, were characterized by a horizontal position near the turning line and distance of $3 \mathrm{~m}$ northeast of the forest line. The plot was shaded in summer from $12 \mathrm{pm}$ till sunset. Thus, all crops were in unfavorable conditions of reduced insolation. 
The soil is black with medium loam. All the experiments and statistical summarizing of the results were made according to the current techniques $[19 ; 20]$.

\section{Results and discussion}

The formation of the root system is decisive for effective conduct of the entire vegetative process. The water supply of the seedlings depends directly on the vegetation of the root system of the sprouted grains, especially when there are no precipitations in the area. After the grain has been put into the soil according to the appropriate heat-humidity regime, the wheat vegetation begins in the following order: absorption of moisture, swelling, protrusion of the central root, protrusion of the pairs of lateral roots, their lengthening, coleoptile growing, protrusion of the first leaf [21].

Due to the phenomenon of geotropism, the non-standard vertical position of grain with the upward orientation of the germ enhances the complex biochemical transformations in the root material. So, the primary roots begin to grow vertically upwards and then the orientation process is activated. As is known from the literature, [22; 23], when there is a random inclination of the root apex, located in the root cap, from the vertical position, the starch grains move to the lower surface of the inclined root due to the gravity, and the molecules of the growth-promoting hormone pass to the upper part.

Due to this hormone, the cells near the top of the surface of the root grow faster than the ones located lower, and thus the root is inclined more, until it takes the position of the root apex oriented downwards. As a result, we have an increased length of the active part of the root, which increases the number of the additional lateral roots. It promotes the release of auxin, which then spreads inside the plant. In the course of the laboratory experiments on the field seeds, the vegetation and productivity parameters were investigated. It could be done taking into consideration the various possible positions of the grain in the soil (Fig. 1)

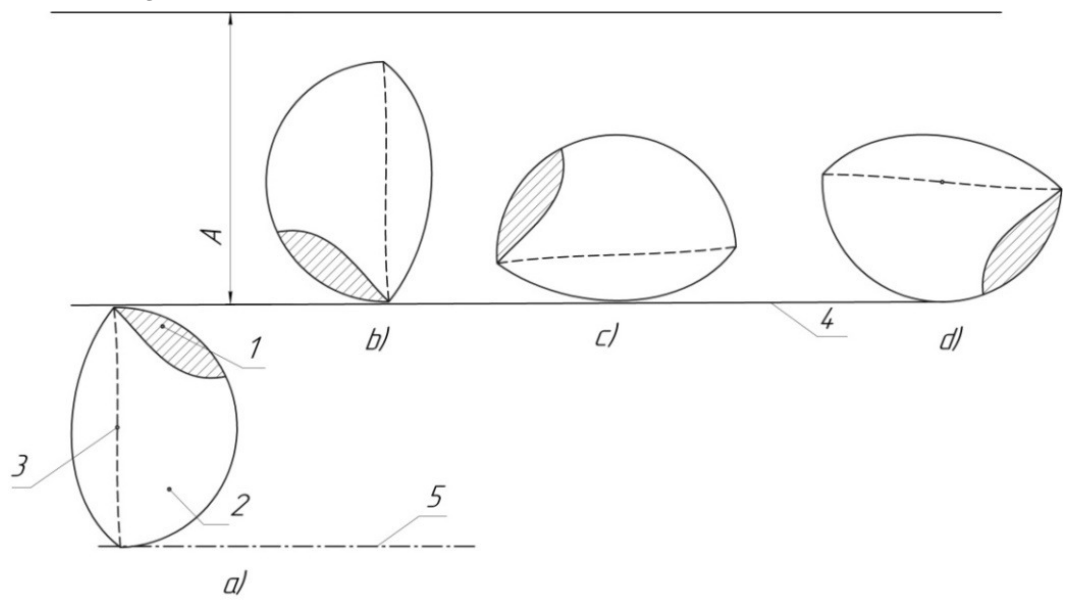

Fig. 1. Scheme of position of wheat grains in soil when germs are placed at same depth: 1 - germ; 2 endosperms; 3 - line of a grain; 4 - surface of the soil; 5 - bottom of the seed drill; A - depth of the seed dill in millimeters; a) germ oriented vertically upwards; b) germ oriented vertically downwards;

c) line oriented horizontally downwards; e) line oriented horizontally upwards

The depth of the placement of the top of the germ is taken as the basis of the research. To put the seed with the germ oriented upwards in a given position during sowing, it is necessary to increase the depth of the seed drill by $8 \mathrm{~mm}$. The depth of sowing A was determined by the height of the placement of the germ of the grain in four variants of seed position. The depth of sowing A had 4 values: 25; 30; $40 ; 50 \mathrm{~mm}$. In the case of a) - the position of the grain germ directed upwards, the seed drill was increased by $8 \mathrm{~mm}$ more than the given depth of the germ, that is: $33 ; 38 ; 48 ; 58 \mathrm{~mm}$. When the grains were put in the ground, the rows were tightened slightly. The visual observation of the yield was carried out every 2 hours until the protrusion of the top of the germ took place (excluding nights). Three days later, the height of the germs was fixed once a day. The number of plants that came up in each batch was determined 9 days later. The experiments were stopped in the phase of the protrusion of two true leaves. The plants were carefully put out of the soil. After the plants were washed and then 
dried in the open air, the height of each plant was measured and the average values were calculated. After the separation of plants, the length of the herb and roots was also determined (Table 1).

The analysis of the results of Table 1 showed that the time spent on germination for grains with germs oriented upwards is 1.5-2 times less than in other cases, and the germination is $10 \%$ higher.

The measurement of the herb, carried out only for one depth of sowing $A=30 \mathrm{~mm}$, was performed nine days later after sowing. It showed the advanced growth of the wheat stem up to $30 \mathrm{~mm}$ for grains with germs oriented downwards in comparison with the rest of the plants 9 days later.

\section{Composite parameters of the beginning of wheat vegetation} in different variants of placement of the seed grains

\begin{tabular}{|c|c|c|c|c|c|c|c|c|c|c|c|}
\hline \multirow{3}{*}{ № } & \multicolumn{9}{|c|}{ Average height of the stem, $\mathrm{mm}$} & \multirow{3}{*}{$\begin{array}{l}\text { Length of the } \\
\text { roots } 9 \text { days } \\
\text { later, mm. }\end{array}$} & \multirow{3}{*}{$\begin{array}{c}\text { Germination, } \\
\%\end{array}$} \\
\hline & \multicolumn{9}{|c|}{ Day after germination } & & \\
\hline & 1 & 2 & 3 & 4 & 5 & 6 & 7 & 8 & 9 & & \\
\hline $\mathrm{a}$ & - & - & 21 & 35 & 69 & 80 & 102 & 142 & 169 & 66 & 98 \\
\hline $\mathrm{b}$ & - & - & - & 14 & 26 & 55 & 86 & 112 & 141 & 59 & 88 \\
\hline $\mathrm{c}$ & - & - & - & 11 & 24 & 52 & 80 & 109 & 133 & 52 & 85 \\
\hline $\mathrm{d}$ & - & - & - & - & 15 & 41 & 60 & 101 & 129 & 49 & 82 \\
\hline
\end{tabular}

In the course of the full experiment, the simultaneous influence of two factors, such as the method of orientation and depth of seeding, on the same parameters, namely, the plant height, the time of the protrusion of seedlings and the germination of plants, was studied (Fig. 2).

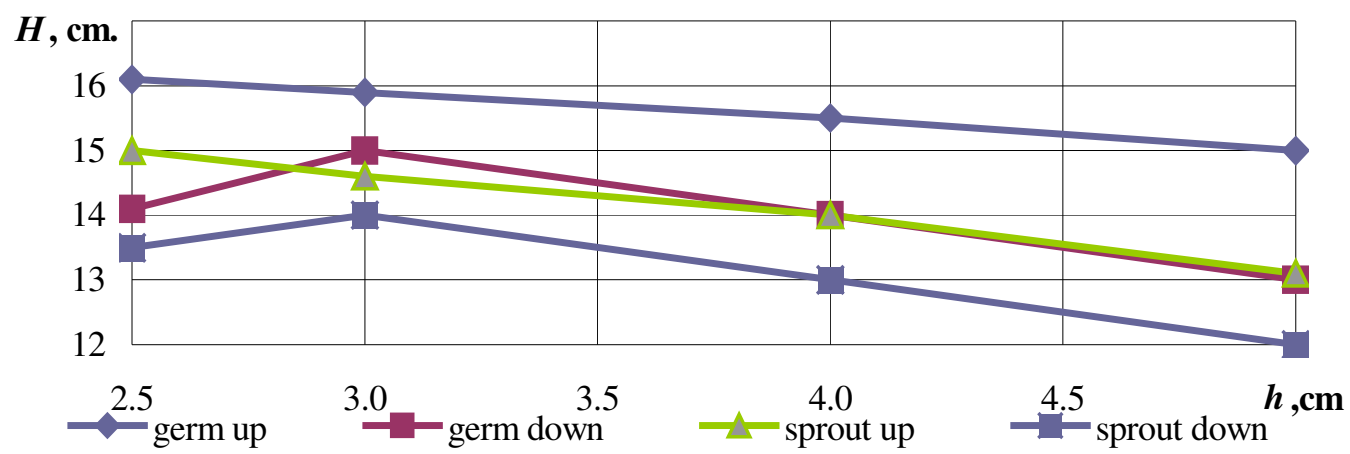

Fig. 2. Influence of depth of sowing and orientation of germ on height of seedlings

While increasing the depth of sowing up to $50 \mathrm{~mm}$, we can observe an increase in the time, necessary for the seedlings to come up, for all methods of direction up to 10-14 hours. The germination is reduced for all four options by an average of $9 \%$.

The laboratory studies of the seed germination of winter wheat according to two variable parameters, such as the method of orientation and depth of sowing, showed a positive result for grains with the germs oriented upwards, which exceeds the other variants by more than $15 \%$, when the depth of sowing varies from $25 \mathrm{~mm}$ to $50 \mathrm{~mm}$, for all of the parameters, such as the time of the protrusion of seedlings, germination, length of the root, stem and plant, as well as the corresponding parts. The best results for all of the parameters can be noticed, when we orient the seed germ upwards, while the depth of sowing is up to $25 \mathrm{~mm}$. Such an increase of the biological parameters of the organogenesis of winter wheat in the stage of germination is one of the proofs of the hypothesis of the stimulating influence (activation) of the vegetation of the plant on a mild strain factor, namely, the inverse position of the plant in the gravitation field at the time of germination. The conclusion as for the mild nature of the activity is based on the fact that such a situation is possible under natural conditions. As a result, the application of an additional mechanism, used to correlate the deviation of the roots from the usual process of the geotropic orientation, promotes the velocity of the growth of the root system of the winter wheat germ.

Taking into account the fact that the moisture of the soil in dry periods, when winter wheat was sown at a small depth of 20-30 mm, was rather insufficient, we cultivated it at a depth of $35 \mathrm{~mm}$. On the experimental plot we applied the disk-taper drill, which provided us with the depth of drills of 
$35 \mathrm{~mm}$ and $43 \mathrm{~mm}$ at additional load. For the entire period of vegetation, the crop nutrition was carried out only once. The wintering is carried out in the first decade of October, actually, on the 4th of October. The seedlings came up 6-9 days later after sowing. In the field, as well as in the laboratory, there was a significant growth acceleration of plants in comparison with the seeds sown by the "germ oriented upwards" method. At the end of October, when the temperature dropped below $0{ }^{\circ} \mathrm{C}$, the vegetation process stopped for the winter period until the middle of March 2017. Before wintering, the difference in the plant height was as follows (in percentage): the largest in the "germ directed vertically upwards" orientation $70 \mathrm{~mm}-100 \%$; "germ directed vertically downwards" orientation 50 $\mathrm{mm}-71,4 \%$; horizontally (randomly) $40 \mathrm{~mm}-57.1 \%$. Before the harvest time, the difference in the stem height significantly decreased - the largest $810 \mathrm{~mm}-100 \% ; 750 \mathrm{~mm}-92.6 \% ; 710 \mathrm{~mm}-$ $87.7 \%$.

The vegetation analysis of winter wheat germs sown at a depth of $35 \mathrm{~mm}$ characterized by various orientation of the grains, in conditions of draught, showed the best results of vegetation for the seed germs oriented vertically upwards. This method is characterized by more active germination and plant growth at the very beginning of the process of vegetation, and this phenomenon was observed until the harvesting of grain. The influence of the application of these technologies on the wheat yield can be estimated by performing a statistical analysis of the quantitative and qualitative parameters of a sample of 55 grain heads obtained by means of different methods of sowing (Table 2 and Table 3 )

Table 2

Distribution of the amount of grains in the head at different sowing options

\begin{tabular}{|c|c|c|c|}
\hline \multirow{2}{*}{$\begin{array}{l}\text { Amount of grains in } \\
\text { the head }\end{array}$} & \multicolumn{3}{|c|}{ Number of heads in a sample with the corresponding amount of grains } \\
\hline & $\begin{array}{c}\text { Germ oriented } \\
\text { vertically up wards }\end{array}$ & $\begin{array}{l}\text { Germ oriented vertically } \\
\text { down wards }\end{array}$ & $\begin{array}{c}\text { Random horizontal } \\
\text { sowing }\end{array}$ \\
\hline 22 & 1 & 1 & 1 \\
\hline 26 & 1 & 6 & 6 \\
\hline 30 & 4 & 14 & 14 \\
\hline 34 & 11 & 7 & 4 \\
\hline 36 & 7 & 13 & 2 \\
\hline 38 & 13 & 5 & 12 \\
\hline 40 & 7 & 2 & 5 \\
\hline 42 & 5 & 4 & 8 \\
\hline 44 & 6 & 3 & 3 \\
\hline $\begin{array}{l}\text { Total amount of } \\
\text { grains }\end{array}$ & 2042 & 1874 & 1930 \\
\hline
\end{tabular}

As a result of the analysis of the distribution of the amount of grains in the head of a random sample of 55 heads, during sowing with different orientations, two most quantitative indices of heads, for the "germ oriented upwards", when the number of seeds varies from 34 to 38 grains in the head, are observed. For the "germ oriented downwards" we can also observe two most quantitative indices, when the number of seeds varies from 30 to 36 , respectively.

Table 3

Distribution of the grain weight in the heads at different sowing options

\begin{tabular}{|c|c|c|c|}
\hline \multirow{2}{*}{ Weight of head, gr } & \multicolumn{3}{|c|}{ Number of heads in a sample with the corresponding weight } \\
\cline { 2 - 4 } & $\begin{array}{c}\text { Germ oriented } \\
\text { vertically up wards }\end{array}$ & $\begin{array}{c}\text { Germ oriented } \\
\text { vertically down wards }\end{array}$ & $\begin{array}{c}\text { Random horizontal } \\
\text { sowing }\end{array}$ \\
\hline 0.8 & 1 & 9 & 9 \\
\hline 1.0 & 2 & 19 & 12 \\
\hline 1.2 & 18 & 6 & 20 \\
\hline 1.4 & 14 & 4 & 3 \\
\hline 1.6 & 11 & 11 & 6 \\
\hline 1.8 & 7 & 4 & 3 \\
\hline 2.0 & 1 & 1 & 1 \\
\hline 2.6 & 1 & 1 & 1 \\
\hline
\end{tabular}


At a horizontal random position of the germ during sowing, there is an alignment of the total number of grains with peaks of the ear, when the number of grains varies from 30 to 38. In all three cases, there is a stratification between the largest and smallest grain content. The least can be observed for the "germ oriented upwards". As a result of the distribution of the number of heads with the corresponding amount of grains, we can hold that there is an increase in the average number of grains in the head, when sowing the seeds with the "germ oriented upwards". It is evidenced by the distribution of the total number of grains in some samples of the corresponding crop.

The analysis of the sample shows that while applying the sowing method, when germs are oriented upwards, there is an increase in the number of heads weighing from 1.2 to 1.6 , which is significantly greater than the other ways of sowing. So, when using the random sowing method, the basic weight of the heads varies from 1 to $1.2 \mathrm{gr}$. While applying the sowing method, when germs are oriented vertically downwards, there are two most weight indices of the head varying from 1 to $1.6 \mathrm{gr}$., but the number of heads weighing 1.6 grams does not exceed the number of heads containing germs oriented upwards. As a result of the distribution of the weight of the grains in the head, we can notice an increase in the average weight of the head containing germs oriented upwards in comparison with other options, which leads to an increase in the total yield.

The average values of the technical yield, along with the germination of the types of grain, are given in Table 4. The best indicators for seed germs oriented upwards are also available in absolute values.

Table 4

Average yield indicators of the germs placed in the soil at a depth of $35 \mathrm{~mm}$

\begin{tabular}{|c|c|c|c|c|c|}
\hline Orientation of grain & $\begin{array}{c}\text { Germination, } \\
\text { \% }\end{array}$ & $\begin{array}{c}\text { Number of } \\
\text { grains in } \\
\text { the head }\end{array}$ & $\begin{array}{c}\text { Weight of } \\
\text { grains in the } \\
\text { head, gr. }\end{array}$ & $\begin{array}{c}\text { Weight of } \\
\mathbf{1 0 0 0} \\
\text { grains, gr. }\end{array}$ & $\begin{array}{c}\text { Yields } \\
\text { Tons } \\
\text { per ha }\end{array}$ \\
\hline $\begin{array}{c}\text { Germ oriented } \\
\text { vertically up wards }\end{array}$ & 98 & 35.27 & 1.535 & 43.50 & 7.04 \\
\hline $\begin{array}{c}\text { Germ oriented } \\
\text { vertically down wards }\end{array}$ & 80 & 33.87 & 1.359 & 40.11 & 5.00 \\
\hline $\begin{array}{c}\text { Random horizontal } \\
\text { sowing }\end{array}$ & 80 & 29.64 & 1.205 & 40.68 & 5.31 \\
\hline
\end{tabular}

The average yield indicators showed a significant increase of the yield mainly due to two factors, namely, high germination and head fullness compared to the traditional method of sowing. The statistical data of the distribution of the number of grains in the head point out the most quantitative increase of grains in the heads, when germs are oriented upwards- up to 13 heads containing 38 grains, when germs are oriented downwards- up to 14 heads containing 30 grains, by means of application of the horizontal method - up to 12 heads containing 38 grains. But it should be noted that there is a quantitative increase of grains of small heads. Hence, we can observe the most grain weight in the heads varying from 1.2 to $1.3 \mathrm{gr}$. and the smallest amount of the immature heads in case of the application of the sowing method when germs are oriented upwards. For two other options, more heads have reduced weight varying from 0.8 to 1.1 gr. These data indicate the improvement of plant vegetation, which entered the stage of formation and accumulation of nutrients in seeds, namely, grains. The results show that the method of sowing the germ upwards is more preferable, which is expressed in the increase in the yield, both in quantitative and qualitative evaluation, and indicate the possibility to control the yield of grain of short-stemmed winter wheat and the necessity to create the technical facilities for the process of sowing oriented specially.

\section{Conclusions}

1. The researches of the influence of the geometric orientation of the "germ" of winter wheat in the soil during sowing showed the differences in the vegetation of the sprouts and root system at the beginning of vegetation. It was established that when we orient the germ upwards, the growth of the primary roots and sprouts increases, which causes the length promotion by $18.9 \%$, in comparison with the samples placed randomly. It should be noted, that due to upward orientation of the germ the germination is up to $98 \%$, which is $15 \%$ more, compared to the control sample. 
2. During the period of vegetation in the field, when germs are oriented vertically upwards, compared to the alternative, when germs are oriented vertically downwards, we can observe great promotion of vegetation of all parts of the plant, such as: the root system, stem, head and grains. The acceleration, in comparison with other control samples, varying from $28.6 \%$ in autumn and $7.4 \%$ in the period of harvesting, has been established.

3. There are 500 heads containing germs oriented vertically upwards per 1 square meter, there are 35.27 grains in one head in an average, their weight is 1.535 gr., and the weight of 1000 grains is 43.50 gr. There are 410 heads containing germs oriented vertically downwards per 1 square meter, there are 33.87 grains in one head in an average, their weight is 1.359 gr., and the weight of 1000 grains is $40.11 \mathrm{gr}$. When applying the method of random sowing, there are 390 heads per 1 square meter, there are 29.64 grains in one head in an average, their weight is 1.205 gr., the weight of 1000 grains is 40.68 gr. The application of the sowing method with the upward orientation of the germ allowed us to increase the quantity of heads by $28 \%$. The average weight of the head was increased by $18.9 \%$ and the yield was raised by $32.6 \%$.

\section{References}

[1] Morgun V., Schvartau V, Kyryzii D. Potential of the variety as a basis for wheat yield. journal grain №5, 2010 pp. 24-30.

[2] Li N., Zhou C., Sun X., Jing J., Tian X. and Wang L. Effects of ridge tillage and mulching on water availability, grain yield, and water use efficiency in rain-fed winter wheat under different rainfall and nitrogen conditions. Soil and Tillage Research, 179, 2018, pp. 86-95. DOI: 10.1016/S2095-3119(16)61447-8.

[3] Stöckle C.O., Higgins S., Nelson R., Abatzoglou J., Huggins D., Pan W., Karimi T, Antle J., Eigenbrode S.D. Brooks E. Evaluating opportunities for an increased role of winter crops as adaptation to climate change in dryland cropping systems of the U.S. Inland Pacific Northwest. Climatic Change, 146(1-2), 2018, pp. 247-261. doi:10.1007/s10584-017-1950-z

[4] Ali M.H., Hoque M.R., Hassan A.A. Khair A. Effects of deficit irrigation on yield, water productivity, and economic returns of wheat. Agricultural Water Management, 92(3), 2007, pp. 151-161. https://doi.org/10.1016/j.agwat.2007.05.010.

[5] Кулешов Н.Н. Агрономические исследования семян (Agronomical Seed Studies) / M.: Сельхозздат, 1963, 304 с. (In Russian)

[6] Tadesse W., Amri A., Ogbonnaya F., Sanchez-garcia M., Sohail Q. and Baum M. 2-Wheat. Genetic and Genomic Resources for Grain Cereals Improvement. 2015, pp. 82-124. https://doi.org/10.1016/B978-0-12-802000-5.00002-2.

[7] Urruty N., Guyomard H., Tailliez-lefebvre D. and Huyghe C. Variability of winter wheat yield in France under average and unfavourable weather conditions. Field Crops Research, 213, 2017, pp. 29-37. https://doi.org/10.1016/j.fcr.2017.07.018.

[8] Wang L., Sun J., Zhang Z., Xu P. and Shangguan Z. Winter wheat grain yield in response to different production practices and soil fertility in northern China. Soil and Tillage Research, 176, 2018, pp. 10-17. https://doi.org/10.1016/j.still.2017.10.001.

[9] Madaras M., Mayerová M., Kumhálová J. Lipavská J. The influence of mineral fertilisers, farmyard manure, liming and sowing rate on winter wheat grain yields. Plant, Soil and Environment, 64(1), 2018, pp. 38-46. doi: 10.17221/703/2017-PSE

[10] Yin L., Dai X. and He M. Delayed sowing improves nitrogen utilization efficiency in winter wheat without impacting yield. Field Crops Research, 221, 2018, pp. 90-97. https://doi.org/10.1016/j.fcr.2018.02.015.

[11]Колесова Т. К. Методы повышения посевных качеств семян пшеницы: автореферат дис. Кандидат сельскохозяйственных наук (Methods of increasing the sowing qualities of wheat seeds: the author's abstract of Diss. Candidate of Agricultural Sciences): 06.01.09 Новосибирск, 2003. - 22 с. (In Russian)

[12] Levin V.A. Influence of methods of presowing seed treatment on sowing qualities, growth parameters and disease resistance of winter wheat. / Questions of modern science and practice. University of. B.V. Vernadsky. №2(40). 2012. pp. 21-25.

[13] Perveen R., Ali Q., Ashraf M., Al-qurainy F., Jamil Y. and Raza Ahmad M. Effects of different doses of low power continuous wave He-Ne laser radiation on some seed thermodynamic and 
germination parameters, and potential enzymes involved in seed germination of sunflower (Helianthus annuus L.). Photochemistry and photobiology, 86(5), 2010, pp. 1050-1055. doi: 10.1111/j.1751-1097.2010.00782.x.

[14]Патент 2090031 Российская Федерация, IPC6 А 01C 1/00. Метод предпосевной обработки семян / Василенко В.Ф .; Приложение 95112900/13 от 25.07.95; опубл. 09.20.97 (Patent 2090031 The Russian Federation, IPC6 A 01 C 1/00. Method of presowing seed treatment / Vasilenko V.F.; Application 95112900/13 of 25.07.95; publ. 09.20.97)

[15] Levina N.S., Tertyshnaya Y.V., Bidey I.A., Elizarova O.V. and Shibryaeva L.S. Presowing treatment of seeds of spring wheat with low-frequency electromagnetic field. Sel'skokhozyaistvennaya Biologiya, 52(3), 2017, pp. 580-587. doi: 10.15389/agrobiology.2017.3.580eng.

[16] Alikamanoglu S., Sen A. Stimulation of growth and some biochemical parameters by magnetic field in wheat (Triticum aestivum L.) tissue cultures. African Journal of Biotechnology, 10(53), 2011, pp. 10957-10963. https://doi.org/10.5897/AJB11.1479.

[17] Shebanin V.S. Technological liner of the front cover of grain in a high-frequency corona discharge / VS Shebanin, D. L. Koshkin, D.O. Zakharov // Energetiya zhurnikoristuvannya. 2016. - № 2. - pp. 38-43.

[18] Арморов Б.А. Техника полевого опыта (с основами статистической обработки результатов исследований) (Technique of field experience (with the basics of statistical processing of research results)), M .: Агропромиздат, 1985. 351 c. (In Russian)

[19] Budka, A., Łacka, A., Gaj, R., Jajor, E. and Korbas, M. Predicting winter wheat yields by comparing regression equations. Crop Protection, 78, 2015, pp. 84-91. https://doi.org/10.1016/j.cropro.2015.08.006.

[20]Патент України № 113837. МПК А01С 7/00 Спосіб розміщення насіння озимої пшениці у грунті при посіві / Зубко В.М., Сіренко В.Ф., Плавінський В.І., Кузіна Т.В. - u201609785; стверджуючи 11.11.2016; Опублікований 25.04.2017 р., Бюл. № 8/2017. (Patent of Ukraine No. 113837. IPC A01C 7/00 Sposib rozmischennya nasinnia ozimoi ryvody in vrunti pr posiv / Zubko V.M., Sirenko V.F., Plavinsky V.I., Kuzina T.V. - u201609785; claiming. 11/10/2016; publ. 25.04.2017, Bul. № 8/2017.)

[21] Носатовский А.И., Пшеница (Wheat). Москва: Колос, 1965, 586 с.(In Russian)

[22] Tsymbal V.A. "Plants / Parallel World" ./ Vek Publishing House, Fryazino, 2009, 144 p.

[23] Кузнецов В.В., Дмитриева Г.А. Физиология растений (Plant physiology) М.: Высшая школа, 2006, 742 c. (In Russian)

[24]Ma S.C. , Wang T.C., Guan X.K., Zhang X. Effect of sowing time and seeding rate on yield components and water use efficiency of winter wheat by regulating the growth redundancy and physiological traits of root and shoot. Field Crops ResearchVolume 221, 15 May 2018, pp. 166-174.

[25] Andarzian B., Hoogenboom G., Bannayan M., Shirali M., Andarzian B. Determining optimum sowing date of wheat using CSM-CERES-Wheat model. Journal of the Saudi Society of Agricultural Sciences, Volume 14, Issue 2, June 2015, pp. 189-199. 